UOT 544.23.02/.03

\title{
RESEARCH INTO SORBTION PROPERTIES AND STRUCTURES OF POLYMER HYDROGEL IMMOBILIZED BY DOXORUBICIN
}

\author{
S.M. Mammadova, Sh.Z. Tapdigov, S.F. Humbatova, N.A. Zeynalov, \\ A.R. Guliyeva, E.M. Gasımov \\ Acad. M. Nagiyev Institute of Catalysis and Inorganic Chemistry \\ National Academy of Sciences of Azerbaijan \\ H.Cavid ave. 113, Baku AZ 1143, e-mail: Samira m@mail.ru
}

Recieved 21.05.2018

\begin{abstract}
The sorption of doxorubicin by hydrogeles obtained through cross-limking of polyacrylic acid with varied quantity (\%, mass) of $\mathrm{N}, \mathrm{N}$-methylene-bis-acrylamide within $\mathrm{pH}=1 \div 10$ interval for 24 hours was performed. It revealed that protonation of active functional groups of hydrogel in acidic media $(\mathrm{pH} \leq 4)$ impedes electrostatic interaction with identical charges in hydrogel and doxorubicin. A small degree of swelling at low $\mathrm{pH}$ of medium also impedes the penetration of molecule of antibiotic into internal pores of hydrogele. Note that $\mathrm{pH}$ changes toward alkaline medium, deprotonation and thereby negative charging of hydrogele surface leads to the sorption of positively charged molecule of doxorubicin. As the $\mathrm{pH}$ changes to the alkaline, the deprotonation of the hydrogel surface and, on the contrary, the negative loading that causes the easy sorption of positively charged doxorubicin molecule..On the other hand, the high swelling of hydrogel in alkaline medium also contributes to the increase of sorption level. Also, the nature of chemical interaction between hydrogel and antibiotic was examined by infrared spectroscopy methods, as well as by scanning electron microscopy. It found that the relation between the polymer and the doxorubicin occurs mainly due to hydrogen bond, electrostatic and hydrophobic interaction.

Keywords: doxorubicin, immobilization, cross-linking, polyacrylic acid, methylene-bis-acrylamide, hydrogel.
\end{abstract}

\section{INTRODUCTION}

Hydrogels are water swollen polymer matrices, with a huge tendency to absorb water. Their ability to swell under physiological conditions makes them an ideal material for biomedical applications[1].The hydrophilicity of the network is due to the presence of chemical residues such as hydroxyl, carboxyl, amidic, primary amidic, sulphonic, etc. that can be found within the polymer backbone or as lateral chains [2,3]. Moreover, some "intelligent" hydrogels could undergo reversible and significant changes in the structure, shape, and/or property after being exposed to external physical/chemical/mechanical stimuli, such as $\mathrm{pH}$ value, temperature, ionic strength, enzymatic activity, glucose concentration, light, electric and magnetic fields, pressure and solvent composition or combination thereof [4-6].Therefore, these stimuli-sensitives are expected to contribute significantly to the exploration and development of the next generation of biomaterials for biological and biomedical applications, such as self-regulated and site-specific drug delivery systems, specialized separation systems or bioreactors. The polymeric hydrogels from synthetic sources are advantageous, because they usually possess controllable chemical structure and architecture, degradation rates, and mechanical strengths. However, most of them are lacking biological cues for biological applications, especially for proliferation of cells and tissue regeneration [7-9].

With the development of understanding in drug delivery mechanism and cancer pathology, a set of criteria have gradually been established for guiding the preparation of drug delivery system for cancer treatment. Drug delivery system should not cause severe long- 
term side effect, so biocompatible and biodegradable materials have predominantly been used for the development of drug delivery system. In order to effectively kill cancer cells and suppress tumor proliferation, significant drug loadings are required for achieving remarkable therapeutic effect. Stimuli-responsive drug release from drug delivery system in tumor tissue is highly preferred to minimize their systemic toxicity and improve drug delivery efficiency [10-12].

As is known, functionalized polymers [13] and polymer composites with silver nanoparticles are widely used in medicine as carrier to immobilize bio-nanocomposites, bionanocatalysts, antibacterial drugs and biologically active substances depending on their particle size $[14,15]$.

Polymersomes were prepared using poly(ethylene glycol)-b-poly(lysine)-bpoly(caprolactone), biocompatible tri-block copolymer. To chemically cross-link the polymersomes, the primary amine of the triblock copolymer came into reaction with a disulfide-containing cross-linker. Doxorubicin was chosen as a model anti-cancer drug, and was effectively encapsulated into the crosslinked bio-reducible polymersomes. The drugloaded polymersomes were greatly retarded in releasing doxorubicin under physiological conditions ( $\mathrm{pH} 7.4$ ) whereas the release rate of doxorubicin rose remarkably in the presence of $10 \mathrm{mM}$ glutathione mimicking an intracellular environment [16].

The hydrogel with high swelling capacity was synthesized in the present work. The sorption capacity of obtained hydrogel to doxorubicin was studied and the structure of complexes analyzed with the help of IR spectroscopy and scanning electron microscopy.

\section{EXPERIMENTAL \\ 2.1. Materials:}

Average molecular mass of polyacrylic acid (PAA) with purity $90 \%$ is $230 \mathrm{kDa}$ to have been purchased from Fluca. Methylenebis-acrylamide (MBAA) which is used as a crosslink agent was supplied by Sigma Aldrich and both reactives are used without further purification. Doxorubicin hydrochloride (Dox) code ATX L01DB01 came from TEVA Pharmaceutical Industries (Israel). Deionized water which is used for preparation of solutions, diethyl ether to precipitate polyacrylic acid and $\mathrm{NH}_{4} \mathrm{OH}, \mathrm{CH}_{3} \mathrm{COONH}_{4}$, $\mathrm{HCl}, \mathrm{KOH}$ for buffer solutions are chemically pure to come from Aldrich.

\subsection{Methods}

\subsubsection{Preparation of Hydrogel:}

$100 \mathrm{mg}$ PAA is dissolved in $50 \mathrm{~mL}$ of deionized water. Crosslink agent MBAA in 5, $10,15,20 \%$ of polymer mass is added to the solution and mixed for 11 hours. The homogeneous solution is poured into Petri bottle and the solvent is evaporated under normal atmospheric pressure. Thin film is continuously influenced by UV radiation $4 \mathrm{~h}$. After irradiation, the samples are washed twothree times consistently with deionized water, $0.01 \mathrm{~N} \mathrm{HCl}$ and ethanol. Samples are dried up at 313-323 K and brought to a stable weight.

\subsubsection{Absorbtion practices:}

Absorbtion practices: Sorption of Dox was performed with PAA hydrogel by compatible method: $0.5 \mathrm{mg}$ gel obtained from cross-linking of 5, 10, 15 and $20 \%$ ratio (mass) of MBAA which is stored for 24 hours in $10 \mathrm{~mL}$ deionized water. Then, by adding appropriate $5 \mathrm{~mL} 1 \div 10 \mathrm{pH}$ it is kept for 30 min, and Dox solution with $1 \mathrm{~mL} \times 10-3$ $\mathrm{mol} / \mathrm{L}$ concentration is added and kept for 24 hours in dark place. Then the solution is filtered, after the sorption the concentration is determined by comparing the concentration of antibiotic remaining in filtrate and optical density (UV-VIS 1800, SHIMADZU) in 510 $\mathrm{nm}$ area with pre-arranged graphic. According to the difference concentrations, sorption degree (SD, \%) of Dox and sorption capacity (SC, mg/g) of hydrogel for antibiotic are calculated. 


\subsubsection{Structural analysis:}

Functional group confirmations were assessed through the use of FTIRspectroscopy. A film of the nano-fluid was dried up on the glass plate. The decomposition

\section{RESULTS AND DISCUSSION}

It is known that for sorption of organic and inorganic ions of absorbent from aqueous solutions the main affecting factor is $\mathrm{pH}$ of the environment. In considering that the $\mathrm{H}^{+}$and $\mathrm{OH}^{-}$ions in the solution leads to the charging of surface, the volume of absorbent, or in other words, hydrogel is characterized by ionization and thus directly affects the sorption degree of sorbet and sorption capacity of hydrogel. The sorption (in the closed bottle, dark) of hydrogels obtained by cross-linking with MBAA in varied \% (by weight) quantity of PAA with Dox has been carried out in terms of static conditions in the $\mathrm{pH}=1 \div 10$ interval within 24 hours. As $\mathrm{pH}$ of environment rises, the sorption degree in the all samples goes up to $60-70 \%$. In acidic environments $(\mathrm{pH} \leq 4)$, the protonation of active functional groups $(>\mathrm{C}=\mathrm{O}, \quad-\mathrm{OH}$ and $-\mathrm{NH}-)$ occurs in the composition of hydrogels. Both hydrogel and Dox being of identical charge can't provide electrostatic encounter. Also, at low $\mathrm{pH}$ a swelling degree of hydrogel impedes the antibiotic molecule to let into pores of the hydrogel. Sorption of positively charged Dox molecule easily causes deprotonation of hydrogel surface and inversely affects negative charging as $\mathrm{pH}$ environment gets to alkali. of cross-linking PAA was studied with the help of scanning electron microscopy (SEM Sigma VP (Carl Zeiss Jena)).

This time, on another side of alkali environment the hydrogels transition into high swelling shape also helps to increase a sorption degree [17].

Also, it found that when the amount of cross-linking agent changes, a sorption degree changes in all $\mathrm{pH}$ as well. It was established that hydrogel obtained by cross-linking PAA with $10 \%$ MBAA maximally absorbs Dox in the $\mathrm{pH}=8$. It is related to a high swelling degree $(600 \%)$ of hydrogel and the rate of starting concentration of the given Dox in the same $\mathrm{pH}$. Owing to $\mathrm{pH}=8$ sorption equilibrium, the concentration rate is directly related to more optimal swelling degree with the same concentration rate as with hydrogel surface.

Though increasing a swelling degree of hydrogel after $\mathrm{pH}=9$, a sorption degree of Dox falls. In alkali environment, it is resultant in discharging the antibiotic surface and decreasing hydrophilicity.

The above-mentioned results can be seen also in dependence curves of $\mathrm{pH}$ environment (Fig. 1) of sorption capacity for Dox of hydrogels which is obtained by cross-linking of PAA with $5 \div 20 \%$ MBAA.

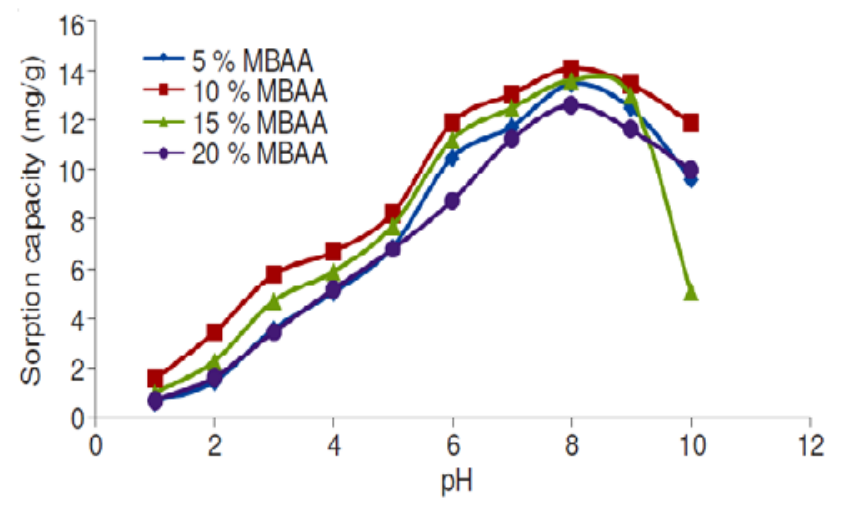

Figure 1. Dependence curves of $\mathrm{pH}$ environment of sorption capacity for doxorubicin hydrochloride of polyacrylic acid based on gel-cross-linking in different $\%$ ratio with methylenebis-acrylamide (MBAA) 
As follows from Fig. 1, the variation characterization of hydrogel sorption capacity has nearly the same shape that with sorption degree. Sorption capacity decreases accordingly to the increase in the quantity of crosslink reagent in hydrogel. It found that in case of sorption capacity for Dox of hydrogel based on PAA cross-linked with $10 \%$ MBAA in $\mathrm{pH}=8$ is $14.12 \mathrm{mg} / \mathrm{g}$, next comes the sorption capacity of polymer cross-linked with $20 \%$ MBAA that makes up $12.64 \mathrm{mg} / \mathrm{g}$. This is explained as being due to the decrease in the size of pores in hydrogel even despite the concentration of functional groups through the rise in the quantity of crosslink reagents. But comparing hydrogels obtained with the presence of 5 and $10 \%$ MBAA, high sorption capacity of hydrogel obtained from $10 \%$ crosslink reagent is related to its optimal value. From spatial point of view, it is more acceptable for Doxmolecule in internal nets. In this respect, antibiotic molecule remains to be more stable and resistant in gel pores. But the polymer is cross-linked with $5 \%$ MBAA because the gel-forming property is not full, sizes of pores are too big and the quantity of active functional groups in crosslink reagents is not enough for Dox, so the concentration of gel has little sorption capacity. Owing to the fact that the antibiotic molecule is not surrounded with enough quantity of functional groups, it is not resistant in the gel.

To determine a type of chemical interaction between Dox molecule and PAAbased gel, structures of starting substances and complexes both are identified with IR spectroscopy methods. We can see enough quantity of active functional groups, if we look at structures of Dox molecule, MBAA and polymer macromolecule.

It revealed that absorption strips having frequency of $1430,1230,1638$ and $3345 \mathrm{~cm}^{-}$ ${ }^{1}$ are observed according to $\mathrm{CH}_{2}=\mathrm{CH}-,>\mathrm{C}=\mathrm{O}$, -
$\mathrm{OH}$ functional groups in FTIR spectrum of PAA. But there are absorption strips 1645, $1445,1650 \mathrm{~cm}^{-1}$ specific to $\mathrm{CH}_{2}=\mathrm{CH}-,>\mathrm{CH}_{2}$, $>\mathrm{C}=\mathrm{O}$ and $-\mathrm{NH}$ groups in crosslink reagent. There are observed decreasing intensity in absorption strip belonging to $>\mathrm{CH}_{2}$ crosslinked polymer spectrum and intensity specific to $-\mathrm{CH}_{3}$ group in spectrum. In $290 \mathrm{~nm}$ and 450 $\mathrm{nm}$, two main maximums are observed in UV spectrum of Dox. In 485 and $525 \mathrm{~nm}$, it is assigned to two smaller absorptions. Chemical shifts occur in absorption strips of functional groups belonging to both crosslink reagent and polymer in FTIR spectrum of PAA-Dox complex. In FTIR spectrum, it is impossible to track functional groups belonging to Doxas antibiotic quantity which is less than $2 \%$ in hydrogel. But one can specify which functional group is actively involved in the absorption strips by PAA and MBAA.

So, chemical shifts of absorption strips specific to $>\mathrm{C}=\mathrm{O},-\mathrm{OH},-\mathrm{NH}-$, - $\mathrm{CO}-\mathrm{NH}$ groups in PAA and MBAA occur to 1670, 1428, 1635, $3340 \mathrm{~cm}^{-1}$ area. It has been mentioned that a little difference between chemical shifts results in creating not covalent bond with Doxand PAA, so it is mainly hydrogen bond and electrostatic interaction that forms a complex between Dox with PAA.

The changes in the morphology and structure of the polymer after cross-linking of PAA with MBAA were analyzed with the help of SEM method. It found that the structural granulation occurs in PAA, thus, the polymer breaks into pieces and the heterogeneous structure becomes available. The cross-linked polymer has a number of layers that point to the cross-linking.

SEM images obtained from different parts of the PAA are given below. The structure of the hydrogel based on the crosslinked PAA with MBAA at a $10 \%$ rate of polymer is given in Fig 2. 


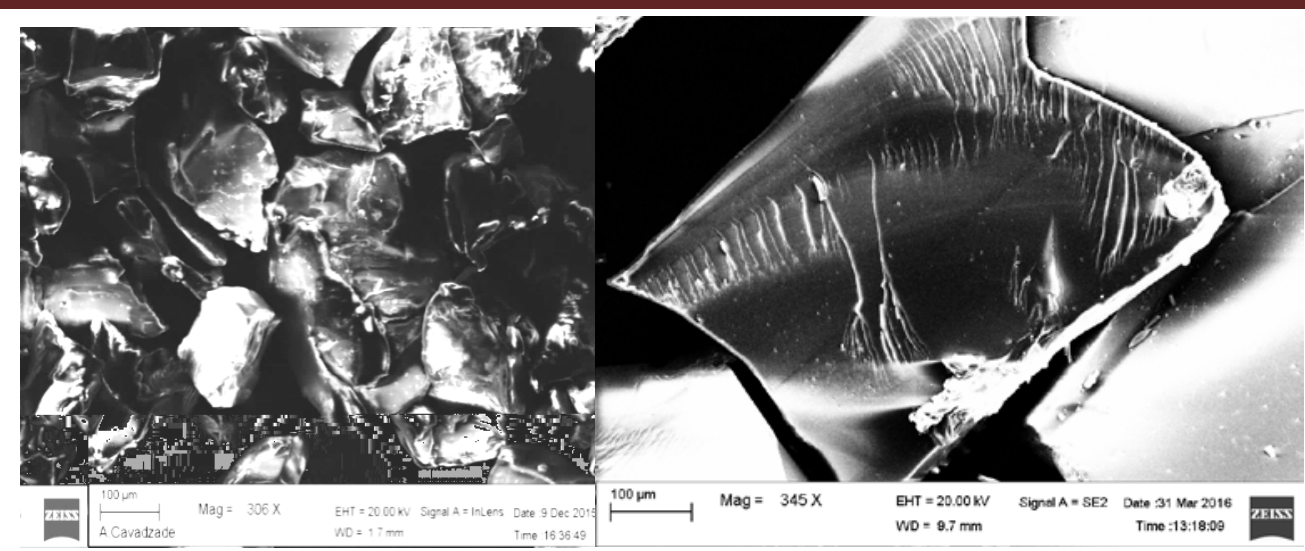

Figure 2. Scanning electron microscopy of $10 \%$ polyacrylic acid crosslinked with MBAA

As it could be seen, fibrous structures are observed in the surface morphology that characterizes the cross-linking. Such relatively regular structures give a clearer representation of $10 \%$ mass of the MBAA. But at the $5 ; 15$; $20 \%$ mass of MBAA, the morphology of the formed gels are irregular, scattered structures that does not characterize heterogeneous or stable cross-linking.

Besides, there is a different morphology in SEM images of PAA with Dox which is cross-linked by $10 \%$ mass of MBAA (Fig. 3).

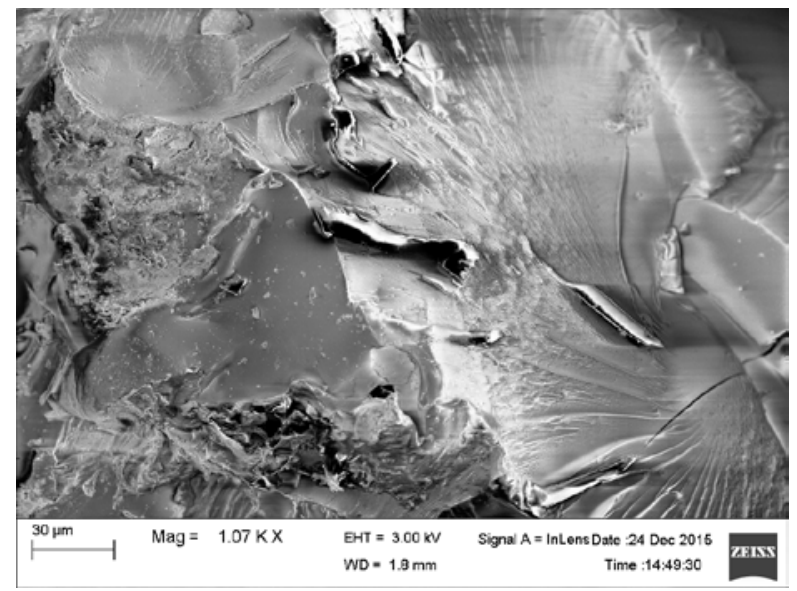

Figure 3. Scanning electron microscopy of crosslinked polyacrylic acid/doxorubicin composites.

Thus, the adsorption gel pores of the Dox molecule breaks the surface morphology of the polymer even despite its significance. As is seen from Figure 3, the smooth surface of the cross-linked polymer is replaced by nonsmooth. That proves the concentration of Dox on the surface of molecule than on inner pores of the gel.

\section{CONCLUSION}

Hydrogel obtained by cross-linking PAA with $10 \%$ MBAA maximally absorbs Dox in $0.05-0.01 \mathrm{mg} / \mathrm{L}$ concentration at the $\mathrm{pH}$ $=8$. At room temperature within 24 hour static condition the sorption rate of Dox is $88 \%$ and sorption capacity is $18-21 \mathrm{mg} / \mathrm{L} 2$ \% (1 g) Dox keeping compositions are used in medical biotechnology for transportation of mentioned antibiotic. It is also used as a long lasting and effective drug.

This work was supported by the Science Development Foundation under the President of the Republic of Azerbaijan- Grant № EIF-KETPL-2-2015-1(25)-56/22/4 


\section{REFERENCES}

1. Gao D., Xu H., Philbert M.A., Kopelman R. Ultrafine hydrogel nanoparticles: synthetic approach and therapeutic application in living cells. J. Angew Chem. Int. Ed.2007, vol. 46, pp. 2224-2227.

2. Lin C.C., Metters A.T. Hydrogels in controlled release formulations: network design and mathematical modeling. J. Adv. Drug. Delivery Rev. 2006, vol. 58, pp. 13791408.

3. Satish C.S., Satish K.P., Shivakumar H.G. Hydrogels as controlled drug delivery systems: Synthesis, crosslinking, water and drug transport mechanism. Ind. J.Pharm. Sci. 2006, vol. 68,pp. 133-40.

4. Qiu Y., Park K. Environment-sensitive hydrogels for drug delivery. J. Adv. Drug Deliv. Rev. 2012, vol. 64, pp. 49-60.

5. Hoffman A.S. Stimuli-responsive polymers: Biomedical applications and challenges for clinicaltranslation. J. Adv. Drug Deliv. Rev. 2013, vol. 65, pp. 10-16.

6. Ward M.A., Georgiou T.K. Thermoresponsive polymers for biomedical applications. J. Polymers. 2011, vol. 3, pp. 1215-1242.

7. Li Y., Rodrigues J., Tomas H. Injectable and biodegradable hydrogels: Gelation, biodegradationand biomedical applications. J. Chem. Soc. Rev. 2012, vol. 41, pp. 2193-2221.

8. Annabi N., Tamayol A., Uquillas J.A., Akbari M., Bertassoni L.E., Cha C., CamciUnal G.,Dokmeci M.R., Peppas N.A., Khademhosseini A. 25th Anniversary article: Rational design andapplications of hydrogels in regenerative medicine. J. Adv. Mater. 2014, vol. 26, pp. 85-124.

9. Caló E., Khutoryanskiy V.V. Biomedical applications of hydrogels: A review of patents andcommercial products. Eur. Polym. J. 2015, vol. 65, pp. 252-267.

10. Fleige E., Quadir M. A., Haag R. Stimuli-responsive polymeric nanocarriers for the controlled transport of active compounds: concepts and applications. J. Adv. Drug Delivery Rev. 2012, vol. 64, pp. 866-884.
11. Du J. Z., Du X. J., Mao C. Q., Wang J. Tailor-Made Dual pH-Sensitive PolymerDoxorubicin Nanoparticles for Efficient Anticancer Drug Delivery. J. Am. Chem. Soc. 2011, vol. 133, pp. 17560-17563.

12. Xiao N. Y., Liang H., Lu J. Degradable and biocompatible aldehyde-functionalized glycopolymer conjugated with doxorubicinvia acid-labile Schiff base linkage for $\mathrm{pH}$ triggered drug release. J. Soft. Matter. 2011, vol. 7, pp. 10834-10840.

13. Mammadova S.M., Tapdigov Sh.Z., Humbatova S.F., Safaraliyeva S.F., Hasanova M.Kh., Zeynalov N.A. Research into hydrogel swelling capacity on the basis of polyacrylic acid and immobilization of doxorubicin thereupon. Kimya Problemlari - Chemical Problems. 2016, no. 4, pp. 377-385. (In Azerbaijan).

14. Humbatova S.F., Mammadova S.M., Tapdiqov Sh.Z., Safarov N.A., Abbasov M.H., Zeynalov N.A. Research into structure of argentium nanoparticles obtained from varied polymer medium. Kimya Problemlari Chemical Problems. 2018, no. 1, pp. 78-85. (In Azerbaijan).

15. Tapdigov Sh.Z., Zeynalov N.A., Taghiyev D.B., Akhmedova U.M., Mammadova A.I., Hasanova M.Kh., Amirov M.A. Research into properties and structure of basic polysaccharide in prunus domestica (cherry). Kimya Problemlari - Chemical Problems. 2018, no. 1, pp. 35-43. (In Azerbaijan).

16. Thavasyappan Thambi V. G., Deepagan H. K., Suh Y. D., Yi G. R., Lee J. Y., Leea D. S. and Park J. H. Biostable and bioreducible polymersomes for intracellular delivery of doxorubicin. J. Polym. Chem. 2014, vol. 5, pp. 4627-4632.

17. Tapdigov Sh.Z., Mammadova S.M. and Zeynalov N.A. Spectroscopic-examined interaction between silver nanocomposites based of poly-N-vinylpyrrolidone and doxorubicin for drug delivery. J. Chem. Chemical Eng. 2014, vol. 8, pp. 800-804. 


\title{
DOKSORUBISINN IMMOBILLIZO OLUNMUS POLIMER GELİN SORBSIYYA XASSOLORİ VӘ QURULUŞUNUN TODQIQI
}

\author{
S.M. Mommodova, SS.Z.Tapdıqov, S.F. Hümbətova, N.A. Zeynalov, \\ A.R. Quliyeva, E.M. Qasımov \\ AMEA akad. M. Nağıyev ad. Kataliz vo Qeyri-üzvi Kimya İnstitutu \\ Bakı ş. H.Cavid pr. 113, AZ 1143, e-mail:Samira_m@mail.ru
}

Poliakril turşusunun müxtəlif miqdar (\% kutla) N,N-metilen-bis-akrilamidla tikilməsindən alınan hidrogellarin doksorubisin ila $p H=1 \div 10$ intervalında 24 saat arzinda sorbsiyası aparılmışdır. Müəyyən olunmuşdur ki, turș mühitlardə ( $\mathrm{pH} \leq 4)$ hidrogelin tərkibindəki aktiv funksional qrupların protonlaşması vo bununla da həm hidrogelin, həm do doksorubisinin eyni yüklü olması onların elektrostatik qarşılaşmasını təmin edə bilmir. Həmçinin aşă̆ pH-larda hidrogelin şişmə dərəcəsinin az olması antibiotik molekulunun hidrogelin daxili masaməlarinə nüfuz etməsinə maneçilik törədir. Mühitin $\mathrm{pH}-\imath$ qələviya doğru dəyişdikcə hidrogelin səthinin deprotonlaşması və əksinə olaraq mənfi yüklənməsi müsbət yüklü doksorubisin molekulunun asanlıqla sorbsiya olunmasina sabəb olur. Digar tərəfdən, sorbsiya dərəcəsinin artmasına qələvi mühitdə hidrogelin yüksək şi̧smə formasına keçməsi də köməklik göstərir. Eyni zamanda hidrogel ila antibiotik arasındakı kimyəvi qarşılıqlı təsirin xarakteri infraqırmızı spektroskopiya, elaca da skanedici elektron mikroskopiya üsulları ila öyranilmişdir. Göstarilmişdir ki, polimerla doksorubisin arasında əlaqə hidrogen rabitəsi, elektrostatik və hidrofob qarşıllqh təsir hesabına baş verir.

Açar sözlar: doksorubisin, immobiizə, tikilmə, poliakril turşusu, metilen-bis-akrilamid, hidrogel.

\section{ИССЛЕДОВАНИЕ СОРБЦИОННЫХ СВОЙСТВ И СТРУКТУРЫ ПОЛИМЕРНОГО ГЕЛЯ, ИММОБИЛИЗОВАННОГО ДОКСОРУБИЦИНОМ}

\section{С.М. Мамедова, Ш.З. Тапдыгов, С.Ф. Гумбатова, Н.А. Зейналов, А.Р. Кулиева, Э.М. Касумов}

\author{
Институт Катализа и Неорганической Химии имени акад. М.Нагиева \\ AZ 1143 Баку, пр.Г.Джавида, 113, e-mail:Samira_m@mail.ru
}

\begin{abstract}
Проведена сорбиия доксорубиина гидрогелем, полученным сиивкой полиакриловой кислоть с разным количеством (\%, масс) N, $N^{\prime}$ метилен-бис-акриламида в интервале $p H=1 \div 10$ в течение 24 часов. Установлено, что протонизирование активных функииональных групп гидрогеля в кислой среде $(\mathrm{pH} \leq 4)$ препятствует электростатическому взаимодействию в связи с одинаковыми зарядами в доксорубицине и гидрогеле. Малая степень набухаемости при низких значениях рН среды также препятствует проникновению молекуль антибиотика во внутренние поры гидрогеля. Изменение $\mathrm{pH}$ в сторону щелочной среды, депротонизирование, и тем самым отрииательное заряжение поверхности гидрогеля приводит $к$ сорбированию положительно заряженной молекуль доксорубицина. С другой стороны, высокая набухаемость гидрогеля в щелочной среде также способствует увеличению степени сорбиии. Также изучен характер химической взаимосвязи между гидрогелем и антибиотиком методами ИК-спектроскопии, а также сканируюшей электронной микроскопии. Показано, что связь между полимером и доксорубицином происходит, в основном за счет водородной связи, электростатического и гидрофобного взаимодействия.
\end{abstract}

Ключевые слова: доксорубииин, иммобилизаџия, сшивание, полиакриловая кислота, метилен-бисакриламид, гидрогель. 